NBER WORKING PAPER SERIES

\title{
INERTIA AND INCENTIVES: BRIDGING ORGANIZATIONAL ECONOMICS AND ORGANIZATIONAL THEORY
}

\author{
Rebecca Henderson \\ Sarah Kaplan \\ Working Paper 11849 \\ http://www.nber.org/papers/w11849 \\ NATIONAL BUREAU OF ECONOMIC RESEARCH \\ 1050 Massachusetts Avenue \\ Cambridge, MA 02138 \\ December 2005
}

This paper has benefited from the comments of participants in the 2004 Organization Science Conference "Frontiers of OS," and from the comments of seminar participants at NYU, Wharton, INSEAD, the Stockholm School of Economics and the London Business School. We would also like to thank Robert Gibbons, Michael Jacobides, Bruce Kogut, Dan Levinthal, William Ocasio, Steven Postrel, Jesper Sørensen, Sid Winter and three anonymous reviewers. All errors or omissions remain our own. The views expressed herein are those of the author(s) and do not necessarily reflect the views of the National Bureau of Economic Research.

(C2005 by Rebecca Henderson and Sarah Kaplan. All rights reserved. Short sections of text, not to exceed two paragraphs, may be quoted without explicit permission provided that full credit, including (C) notice, is given to the source. 
Inertia and Incentives: Bridging Organizational Economics and Organizational Theory

Rebecca Henderson and Sarah Kaplan

NBER Working Paper No. 11849

December 2005

JEL No. L0, M0

\begin{abstract}
$\underline{\text { ABSTRACT }}$
Organizational theorists have long acknowledged the importance of the formal and informal incentives facing a firm's employees, stressing that the political economy of a firm plays a major role in shaping organizational life and firm behavior. Yet the detailed study of incentive systems has traditionally been left in the hands of (organizational) economists, with most organizational theorists focusing their attention on critical problems in culture, network structure, framing and so on - in essence, the social context in which economics and incentive systems are embedded. We argue that this separation of domains is problematic. The economics literature, for example, is unable to explain why organizations should find it difficult to change incentive structures in the face of environmental change, while the organizational literature focuses heavily on the role of inertia as sources of organizational rigidity. Drawing on recent research on incentives in organizational economics and on cognition in organizational theory, we build a framework for the analysis of incentives that highlights the ways in which incentives and cognition - while being analytically distinct concepts - are phenomenologically deeply intertwined. We suggest that incentives and cognition coevolve so that organizational competencies or routines are as much about building knowledge of "what should be rewarded" as they are about "what should be done."

Rebecca Henderson

Sloan School of Management

MIT, E52-543

50 Memorial Drive

Cambridge, MA 02142-1347

and NBER

rhenderson@mit.edu

Sarah Kaplan

University of Pennsylvania

Wharton School

3620 Locust Walk, Suite 2019

Philadelphia, PA 19104

slkaplan@wharton.upenn.edu
\end{abstract}




\section{Introduction}

Organizational theorists have long acknowledged the importance of the formal and informal incentives facing a firm's employees, stressing that the political economy of a firm plays a major role in shaping organizational life and firm behavior (Ancona, Kochan, Scully, Van Maanen, \& Westney 1999; Pfeffer 1990). Yet the detailed study of incentive systems has traditionally been left in the hands of (organizational) economists, with most organizational theorists focusing their attention on critical problems in culture, network structure, framing and so on - in essence, the social context in which economics and incentive systems are embedded (Stark 2000).

We argue that this separation of domains is problematic, in particular when endeavoring to understand organizational rigidity in the face of environmental change. While such inertial behavior has been variously attributed by organizational theorists to competency traps (LeonardBarton 1992; Nelson \& Winter 1982) and cognitive limits (Barr, Stimpert, \& Huff 1992; Tripsas \& Gavetti 2000), it is also clear that difficulties in creating new incentive systems to match new circumstances play a critical role (Gavetti, Henderson, \& Giorgi 2004; Ghoshal 1992). In this paper, we use the problems experienced by established firms attempting to create new businesses to focus attention on the forces that shape and constrain the development of new incentive systems. We believe that this phenomenon presents a particularly appealing object of study, first, because creating appropriate incentive regimes is widely understood to be a critical part of facilitating organizational response to change of all kinds, and, second, because a careful unpacking of this issue has the potential to lay the foundation for a more integrated understanding of the relationship between cognition and agency. 
Drawing on recent research on incentives in organizational economics and on the evolution of cognitive frames in the organizational literature, we build a framework for the analysis of incentives that highlights the ways in which incentives and cognition, while being analytically distinct concepts, are phenomenologically deeply intertwined. We suggest that incentives and cognition coevolve so that organizational competencies or routines are as much about building knowledge of "what should be rewarded" as they are about "what should be done." We argue that this recognition has important implications for our understanding of how the interaction of cognition and incentives constrains and enables the evolution of organizational competencies and that it opens up important new areas for further research.

The paper begins by briefly reviewing the existing research that has explored the difficulties established firms face in responding effectively to new opportunities. In particular, we look at the complexities involved in creating effective "ambidextrous" organizations - those in which one part of the organization continues to operate much as before while another attempts to combine the best aspects of small, entrepreneurial firms with the advantages derived from being part of a more established company. The creation of ambidextrous organizations has been widely recommended as an appropriate solution to the problems encountered by firms that seek to enter significantly different markets (often using radical technologies) yet wish to take advantage of their existing competencies and assets (Tushman \& O'Reilly 1997).

A common recommendation, for example, is that the people employed by the new unit be managed using new incentive structures (Block \& MacMillan 1993). This would seem to be sensible advice. It is unlikely that the ways one can most effectively motivate and reward the employees of a stable, slow-growing business focused on operational excellence would be identical to the ways one would most effectively motivate and reward the employees of a fast- 
moving, entrepreneurial unit designed to generate growth. Yet despite widespread agreement that creating these separate units within the larger organization is an appropriate course of action (Christensen 1997; Utterback 1994; Wheelwright \& Clark 1992), the track record of firms attempting to implement them has been mixed. The new units often have difficulty revisiting deeply held assumptions about the appropriate role of new technology, the structure of the market and the usefulness of alternative business models. Moreover, a surprisingly large number of older, more established firms impose incentive structures on their new units that retain key features of those in use in their existing, more mature businesses. While many managers recognize that radically different incentive structures might encourage their employees to pursue more high-risk, more radical technologies, they often hesitate to implement them.

Striking successes, like that documented in The Soul of a New Machine (Kidder 1981) and the case of Teradyne's entry into the CMOS testing business (Bower 1997) are counterbalanced by many accounts of firms whose new business units appear neither to have embodied the energy and creativity of their more entrepreneurial rivals nor to have successfully taken advantage of the resources available through their parent firm. (Later in the paper, we explore, for example, Kodak's troubled entry into digital photography and Andersen Consulting's attempts to move into more strategic consulting.) Despite a sizable literature in the area, however, our understanding of exactly why it should be so difficult to build an effective ambidextrous organization remains limited.

We next turn to a brief summary of recent research in incentive theory. A critical component of this discussion is the translation of ideas and terms that are relatively unproblematic from an economics perspective into the messy reality of a complex organization faced with the uncertainties of environmental or technical change. Our analysis highlights the 
fact that the cognitive and incentive mechanisms of an organization are intimately linked at the most granular level. Cognitive frames not only serve as a means of capturing and sharing information but also shape individual interests and the effectiveness of incentives employed by the firm. In this sense, the distinction between cognitive problems and agency or incentive problems may be analytically convenient but reflects a fundamental misapprehension of the roots of action in a modern firm, in which these factors co-evolve through an intensely pathdependent, reciprocal process.

This line of argument allows us to move beyond the existing literature and to develop a deep understanding of the constraints that established firms face as they attempt to build appropriate incentive systems for new ventures. Using some simple analytic formalizations to clarify ideas, we argue first that, as several economist have suggested, in a well-established firm incentives are likely to be based upon measures that are subject to interpretation. However, where the economics literature assumes that even if measures are subjective, they can be instantaneously observed by everyone in the firm, we argue that building a common understanding of what's possible and what's costly, of the relationships between actions and outcomes and of how appropriate actions can be observed or tracked is not an easy enterprise. Each of these elements can be quite ambiguous, with its meaning only emerging over time as a result of shared history and the slow development of collective cognitive frames. As a result, we believe that in any situation of even moderate complexity, incentives are always defined in relation to the existing cognitive frames of the firm's managers and employees.

Second, also as several economists have suggested, we argue that in an established firm the incentive system is likely to be embodied in a series of relational contracts. But where the economics literature, drawing on the assumption of immediately available, common information, 
suggests that relational contracts are relatively unproblematic to construct, we hypothesize, in contrast, that employees trust that employers will enforce these contracts because years of experience have forged a shared knowledge (cognitive frames) of the terms of the contracts and a history of honoring them. We explore the relationship between these contracts and the cognitive frames within the firm to suggest that the local knowledge of a firm that is embedded in routines is thus not just about how to get the work done but also about what work will be rewarded.

We then turn to a discussion of why these kinds of incentive regimes may be so difficult to change, and thus of why the entrepreneurial units of established firms are often managed using incentive schemes closely drawn from the more conventional portions of the business. The economics literature has no theory as to why incentive regimes should be difficult to change. Drawing on our model of incentives as profoundly intertwined with the cognitive history and experience of the firm, we suggest that the development of a new incentive regime faces three core problems. First, interests are context dependent; so, as the market changes, even employees may be unclear about their interests in the new situation. Second, neither employers nor employees have full knowledge of either the kinds of behaviors that are likely to be effective in a new arena or of the measures that might signal that these behaviors have occurred. Third, even if managers can develop new measures, they may find it difficult to develop new relational contracts. The new measures are likely to be noisier, creating problems in committing to appropriate behavior. This problem is often compounded by the fact that the firm has no history of rewarding people who behave in the desired new ways, leaving managers and their employees without a familiar - and hence effective - relational contract. In addition, moving to the use of new measures and establishing a new relational contract may be viewed as a violation of the existing relational contract, making it difficult to manage the established part of enterprise. 
These problems are, of course, encountered by any firm - including small entrepreneurial startups - attempting to do something entirely new. However, we argue that the power of embedded cognitive frames about how to do business in combination with the need to maintain the credibility of existing relational contracts is likely to lead established firms to develop new incentives that may be deeply anchored on existing incentive regimes, even if they are significantly less effective than those developed by entrepreneurial startups. We close by suggesting that the recognition that incentives and cognition are tightly intertwined opens up new insight into the nature of organizational competencies and suggests some intriguing directions for further research.

\section{Building ambidextrous organizations}

The difficulties experienced by established firms attempting to respond to discontinuous or radical shifts in their environment are well documented in the literature (c.f., a review by Chesbrough 2001). In a wide array of industries, including watches (Landes 1969), disk drives (Christensen \& Rosenbloom 1995), photolithography (Henderson \& Clark 1990), calculators (Majumdar 1982), pens, semiconductors and locomotives (Cooper \& Schendel 1976), new entrants displaced incumbents as market leaders when radically new technology invaded the market. The more "rugged" the new landscape (i.e., the more uncertain for the actor), the more likely the incumbent will fail (Levinthal 1997). Although there is evidence that some firms manage to enter new fields quite successfully (Chandy \& Tellis 2000; Christensen, Suarez, \& Utterback 1998; Rothaermel 2001; Tripsas 1997), in general the investments that established firms make in significantly different technologies appear to be less productive than those made by new entrants (Henderson 1993). Stories from Andersen Consulting's attempts to enter strategic business integration and Kodak's efforts to transition to digital technologies provide 
striking examples of the problems established firms encounter, and of the ways in which incentive regimes may be deeply constrained by the company's prior experience and cognitive frames.

Andersen Consulting. In an attempt to generate further growth in its core information technology (IT) business, in the late eighties Andersen began to hire numbers of specialist strategy consultants from outside the company for a new line of business in strategic business integration. As Ghoshal (1992) reports, these new employees were typically significantly more experienced than the usual Andersen recruits (who were largely undergraduates) and accustomed to much more aggressive individual performance incentives than was the norm in Andersen's IT business. The new hires requested the kinds of aggressive compensation systems they had been accustomed to in pure-play strategy consulting firms, but these desires met with significant resistance. The existing employees (generalist IT consultants) had grown over the years to trust the traditional compensation system, one which did not include bonuses for consultants. "It may not be perfect every year," said one partner, "but over a period of time, everyone seems to get what they are due" (p. 8).

This compensation system had been reinforced through extensive training and socialization of all new hires. Attempts to change it were complicated by the fact that no one in Andersen really knew how this new business would operate or what it would take to succeed. "Old line" Andersen employees, according to one of Andersen's managing partners, "were in a very depressed state [because] they didn't know what the company was trying to do...They didn't understand the IT strategy or the business strategy..." (p. 12). Vernon Ellis, the head of Andersen, admitted that even well into the implementation of the new strategy, "There were still conferences and debates on the strategy, which reflects an emerging understanding with no clear 
answer yet." Similarly, the generalist consultants complained that the new hires were not doing things the "Andersen Way" which resulted in a "loss of trust" in the organization (p. 18). As a result, rather than putting in "McKinsey" style compensation systems, Andersen experimented with a variety of structures that were much closer in form to their existing incentive arrangements, including trying to hire strategy consultants that more closely fit the profile of existing IT consultants (which defeated the purpose of building new and different capabilities). The new hires found the use of old incentive systems deeply puzzling, and often subsequently left the firm, thus making it substantially more difficult to build the new business (Personal Communication, 2005).

Kodak. In facing the challenge of digital imaging, Kodak has brought to the table a hugely powerful brand name, years of accumulated experience in understanding human interaction with images of all kinds and a dominant position in many retail channels. The company clearly acknowledged that this new form of imaging required a transition of technical capabilities from chemical to digital. Not only did they hire new talent in electronics at all levels of the organization, but they have also divested themselves of chemically-related business that might distract attention from the new opportunity, including the sale of Sterling Drugs and the historically important Eastman Chemical in 1993. At the same time, such significantly different opportunities required the firm to develop significantly different ways of working: digital imaging proved to be dissimilar from conventional imaging technology in many more ways than just the technical (Gavetti et al. 2004). However many existing senior managers wanted to implement the new technologies according to the traditional economic formulas and ways of doing business established years previously by George Eastman himself. As John White, an executive hired by Kodak to push into this new business arena, said, 
"Kodak wanted to get into the digital business, but they wanted to do it in their own way, from Rochester and largely with their own people. That meant it wasn't going to work. The difference between their traditional business and digital is so great. The tempo is different. The kinds of skills you need are different. Kay [Whitmore, President] and Colby [Chandler, CEO] would tell you they wanted to change, but they didn't want to force the pain on the organization." (Gavetti et al. 2004: 4)

The digital business required a fundamentally different business model that many in the company found difficult to understand or internalize: the film business was highly profitable and people couldn't imagine anything else "legal" that would have the same levels of profitability (Gavetti et al. 2004: 5). Three years of attempts to develop a hybrid business ("film-based digital imaging" and the photo CD) were widely viewed as a failure. Kodak eventually created a new digital imaging division separate from the traditional photography group, but it took many years for the business to reach profitability.

In both the Andersen and Kodak cases, conflicts around the understanding of what the new business would be and around how to reward the people building it led to failures in developing the ambidextrous organizations required to pursue the opportunity. The existing literature, however, is divided as to why these conflicts develop.

The most basic explanation for the difficulties that established firms face in responding to these kinds of challenges focuses on the importance of initial conditions in shaping the capabilities and responses of organizations (Hannan \& Freeman 1984; Stinchcombe 1965). If differences in founding conditions mean that firms are fundamentally different from each other, those firms that survive to become dominant in a particular industry do so because they possess assets and capabilities that are better suited to the characteristics of that industry. Thus a major shift, such as a radical technological change, will make these differences a source of liability rather than an advantage, while newly founded firms, or those entering from other industries 
whose unique blueprint is better suited to the new conditions, will survive. This explanation is logically compelling, but it leaves unanswered the precise question of the source and nature of these differences and of the conditions under which they can be manipulated or changed.

Nelson and Winter's (1982) work on the importance of routines in shaping the behavior of the firm provides us with some insight into this question. They suggest that historically derived routines make it difficult for the firm to do anything but search locally - and hence doubly difficult to do anything entirely new. Routines inherited from experience with the previous generation of technology cannot be easily translated to a new setting. ${ }^{1}$ Tushman and colleagues have suggested that firms are more or less vulnerable to technological change depending on whether the change will enhance or destroy these existing routines (which they call “competencies"), where a shift in emphasis among existing competencies will be less fatal than a wholesale shift to a new arena (Gatignon, Tushman, Smith, \& Anderson 2002; Tushman \& Anderson 1986).

This stream of explanations focuses on what firms are able to do. Explanations rooted in the study of cognitive frames have focused instead on what managers (and employees) think. Drawing on the observation that managerial cognitive frames shape the interpretive processes of the organization, this work suggests that frames are the basis of strategic choice and action (Daft \& Weick 1984; Gioia 1986; Kiesler \& Sproull 1982; Ocasio 1997). Over time, research in this area argues, top management teams develop a set of shared beliefs (collective cognitive frames)

\footnotetext{
${ }^{1}$ Yet another stream of work in this tradition focuses on the constraints imposed by particular organizational structures. This idea dates back at least to Burns and Stalker (1961), whose distinction between "organic" and "mechanistic" organizations continues to echo in the popular literature. Viewed from this perspective, established firms fail because they are too rule-bound, lacking in creativity, and too slow to respond effectively to significant change.
} 
about how a firm makes money. In implementing a new technology, managers base their expectations of commercial success on these collective frames. Even if these frames are inappropriate in a new environment, managers may find it difficult to change them, particularly if this highly tacit accumulated knowledge provides the underlying raison d'être of the firm (Kogut \& Zander 1992). In a longitudinal comparison of two railway companies, for instance, Barr, Stimpert and Huff (1992) found that the top management teams' relative abilities to interpret environmental changes and translate those insights into strategic action determined the success of one firm and the failure of the other to adapt. Tripsas and Gavetti (2000) found that the Polaroid top management team experienced difficulty overcoming their belief in the efficacy of a particular business model for commercializing imaging technologies even when it prove ineffective in the digital world. In these stories, firms do not get their response right because they do not think about the nature of the problem right.

Henderson and Clark's (1990) analysis of firms' responses to radical changes in the photolithography business integrates these two mechanisms by suggesting that some routines may have a very significant cognitive component. They argue that firms' inability to respond to what they call "architectural" innovation is a function of a continued reliance on accumulated knowledge (information filters, mental models and problem-solving strategies) that reflects the architecture of the previous generation of products. While the authors do not expand on these concepts, we interpret "information filters" and "mental models" perhaps even "problem-solving strategies" as particular aspects of the collective cognitive frames that becomes embedded in the organization.

Indeed their argument foreshadows the arguments we develop below in our discussion of the interplay between incentives and cognition in shaping established firm response to radical 
technological change. They focus on disruptions in the architectural knowledge (collective frames) of the firm. We argue that, as these collective frames become more deeply embedded in the organization, they become implicated in the incentive system and the mutual understanding of "how we do things around here." Architectural innovations thus require not only new cognitive frames, but also new incentives - and building a new incentive regime may be particularly difficult in the face of deeply embedded cognitive frames. It is to this argument that we now turn.

\section{Organizational economics and organizational rigidities}

The idea that it may be difficult to sustain significantly different incentive regimes within the same organization is not a new one, although to the best of our knowledge few organizational researchers have suggested that this plays a major role in contributing to organizational inertia. One long-standing perspective on this problem focuses on the problem of equity, suggesting that internal norms make it difficult to offer the employees of a new unit incentives that are significantly more high powered than those offered to employees in the existing firm (Adams 1963; Block \& MacMillan 1993; Block \& Ornati 1987; Chesborough 1999; Lind \& Tyler 1988). ${ }^{2}$ While norms of equity clearly play an important role in shaping organizational behavior,

\footnotetext{
${ }^{2}$ Managers have attempted to correct for incentives problems by splitting out the development of the new technology into a new unit in the organization, often in a location geographically remote from headquarters. Block and MacMillan (1993: 137-138) lay out the tensions associated with this approach. For a new venture to be successful, it must have the support of the parent organization. But, a sure way to undermine that support is to provide incentives that are perceived as unfair by employees in the parent. Yet it is precisely these kinds of incentives that are required to get the new venture off the ground. Corporate managers then decide to create a separate unit and move it far away from the rest of the company precisely so that they can mask the inequity in incentives structures. The net result is that the new venture can no longer benefit from the knowledge or
} 
we do not believe that they can, alone, explain why the incentive regimes in many new units are so similar to that of their parent company. It is often the case, for example, that employees working in sales may be much more highly compensated than many other employees, and that this creates relatively little tension as other employees come to accept that working in sales is different, difficult and unpleasant or simply that salespeople need different forms of compensation to keep them motivated because they are a "different breed" (Anderson \& Trinkle 2005).

Closer in spirit to our core argument here, Foss (2003) notes that the difficulties managers encounter in executing what he calls "selective intervention" (only partially committing to a new system) are likely to be even more extreme in turbulent industries, suggesting that an inability to commit to a new incentive regime may lie behind the difficulties in creating entrepreneurial ventures. Similarly Nelson and Winter (1982) assert that one of the reasons organizational routines evolve only incrementally is that they sustain an "organizational truce" between the members of the firm about what the business is and what actions should be taken. Hannan and Freeman's (1984) focus on the importance of accountability - not only to external stakeholders but also to employees - suggests that stability in structure and process serves to reassure employees that their commitment to the organization will continue to be valued. More recently, Coriat and Dosi (1998) have argued that routines can be interpreted as "a locus of conflict, governance and a way of codifying micro-economic incentives and constraints" (p. 104). In this sense, routines and capabilities can be understood to have both a cognitive (how 
things are done) and motivational (what gets rewarded) dimension (Cohendet \& Llerena 2003; Dosi, Levinthal, \& Marengo 2003).

Here we expand on these ideas by drawing on recent work in organizational economics to focus in detail on the dynamics that make incentive regimes difficult to change in the face of significant external shifts. We believe that by reinterpreting and extending the formalizations introduced by this literature in the light of organizational theory we can begin to provide a framework for understanding why incentive regimes are an essential but incomplete explanation of organizational inertia and the failures in creating ambidextrous organizations that function well. We show that incentives cannot be understood separately from the cognitive frames and interests of both employees and employers in any complex organization and that these factors interact to produce the inertial effects we observe in example after example of companies facing change.

A brief excursion into algebra serves to clarify ideas. ${ }^{3}$

Assume, first, that an employee's actions can be represented as a vector, a. Some of these actions will be valuable to a firm, but others will not. Some are intrinsically pleasurable to the employee while others are costly and unpleasant. The full mapping from the vector of actions, a, to an employee's utility or happiness on the job is given by:

$$
\mathrm{u}(\mathrm{a})=\mathbf{h} \cdot \mathbf{a}+\varepsilon_{\mathrm{u}}
$$

\footnotetext{
${ }^{3}$ The discussion that follows draws extensively on recent work in organizational economics, including papers by Holmstrom and Milgrom (Holmstrom 1989; Holmstrom \& Milgrom 1991), Baker, Gibbons and Murphy (1994; 2001) and Levin (2003). The reader should be aware that this literature is large and complex and that we summarize it very briefly here. Any errors are entirely our responsibility.
} 
where for simplicity we suppress all subscripts for time and employees. An employer's benefit or output from the same vector of actions is given by $\mathrm{y}$, where:

$$
y(a)=\mathbf{f} \cdot \mathbf{a}+\varepsilon_{\mathrm{y}}
$$

Unless there is perfect alignment between the actions that an employee would most like to take and the success of the organization (as could be the case in a community symphony orchestra or a leading edge research institute, where the intrinsic pleasure of the work is very high), the divergence between $\mathrm{u}(\mathbf{a})$ and $\mathrm{y}$ (a) will lead firms to pay their employees wages. In the ideal case, in which firms could observe every action of the employee, firms would pay according to the equation:

$$
\mathrm{w}(\mathrm{a})=\mathrm{w}_{\mathrm{o}}+\mathbf{b} \cdot \mathbf{a}
$$

where $\mathrm{w}_{\mathrm{o}}$ is the fixed component of total compensation, $\mathrm{w}$, and $\mathrm{b}$ is the bonus paid by the firm as a function of the actions taken by the employees. Note that $w$ is not simply monetary compensation, but the full value of all the ways a firm can reward an employee, including promotions, corner offices and other perks. The firm would then maximize:

$$
\Pi=\mathrm{y}(\mathbf{a})-\mathrm{w}(\mathbf{a})
$$

And employees total utility $\mathrm{U}$, is given by:

$$
\mathrm{U}(\mathbf{a}, \mathrm{w})=\mathrm{u}(\mathbf{a})+\mathrm{w}(\mathbf{a})
$$

There is some evidence that when the actions that an employee can undertake can be easily measured, firms do use a wage contract of this type. For example, Lazear (2000) shows that some automobile window glass installers are rewarded in this way. In the case of more complex organizations and more complex tasks, however, it is often very difficult to observe 
either the actions taken by employees, a, or, more subtly, exactly how these actions contribute to the generation of useful output for the firm, y. Consider the case of a research scientist working for a large pharmaceutical firm, for example. Much of her work occurs in groups or teams. What are her actions? How does one observe "thinking up creative ideas?" When a scientist goes to a conference in Hawaii, for example, is she indulging in actions that improve her personal utility (u) or making valuable scientific contacts that will ultimately lead to the discovery of important new drugs?

Faced with this complexity, the economics literature suggests that employers will make wage contracts contingent not on a or y, which are usually impossible to observe, but on proxies or signals, $\mathrm{p}$, and offer wage contracts of the form:

$$
\mathrm{w}(\mathrm{a})=\mathrm{w}_{\mathrm{o}}+\mathbf{b} \cdot \mathbf{p}
$$

These proxies may be readily measurable - such as the numbers of patents applied for or granted - or may be much more difficult to measure - such as the number of "good" ideas generated by particular inviduals. A common proxy, for example, is the subjective assessment by the employee's immediate supervisor. In a modern organization, the incentive regime typically includes a complex mix of objective measures ("If you make this quarter's numbers you will receive a bonus of $\$ \mathrm{x}$ ") and subjective measures ("If I think you're doing a good job this year I'll promote you").

As several organizational economists have suggested, however, an incentive regime of the form expressed in equation (6) may be all very well in theory but will create all kinds of problems in practice. In the first place, any particular set of metrics p may or may not be a good measure of the actions the firm would prefer employees to take (Kerr 1975). Staying late at 
work, for example, may or may not be correlated with working hard, and being very polite, or the functional equivalent, to one's immediate supervisor (the economists call this kind of thing "influence costs") may result in high reported measures of $\mathbf{p}$ without much useful action. Organizational economists have explored the consequences of this divergence in some depth, pointing out, for example, that firms are likely to put more or less weight on $\mathbf{p}$ (higher or lower values of the bonus, $b$ ), depending on how accurate a measure of useful action $\mathbf{p}$ is.

A further complication is that while a firm might announce that it will compensate its employees on the basis of the vector (p), to the extent that $\mathrm{p}$ is noncontractible (i.e., the firm cannot write a legally enforceable contract around it), then employees might not find such an announcement credible. As a sales representative, for example, with compensation based around well-defined metrics, I could in principle seek legal redress if my employer failed to give me a promised bonus. However, suing on the basis of the claim that "I worked my heart out to start up the Chinese subsidiary and they promised that if I did a good job I'd get a chance to move up in the organization" is likely to be much more difficult.

In such cases, several researchers have suggested that the incentive regime expressed in equation (6) becomes embedded in a set of relational contracts between employee and employers, or in other words, a contract that employers honor because the long-term benefits of enforcing it are greater than the short-term benefits of reneging on it. From the perspective of the economics literature, this kind of contract is intriguing in that it is not written down or legally enforceable, but it is seen as otherwise unproblematic. Both employers and employed are assumed to have full information about all the relevant variables, and can be trusted to uphold the contract because they have no incentive to break it. 
Most importantly, the economics literature has no model of why such a contract should be difficult to change. From their standpoint, if the world changes such that the firm should reward a different set of subjective measures, the firm can simply announce the change. Employees will know that it is rational for the firm to enforce the new contract, and employers will know that employees will therefore behave appropriately. Both parties will move seamlessly to the new equilibrium and change will be unproblematic.

From an organizational perspective, however, the idea is much more problematic.

\section{Building a new incentive regime}

For a firm to be able to derive the "optimal" contract (equation 6), a great deal of knowledge has to be in place - and known to everyone on both sides of the contract. Managers need to understand what the possible set of actions is, how enjoyable or costly these actions are going to be for the individual employee (equation 1), and the link between these actions and useful output (equation 2). Then they need to be able to design a relational contract between the firm and the employees that will persuade the employees that the firm will honor such a promise (equation 6). In a world of perfect information in which new relational contracts can be simply announced, this would not, of course, be a problem - but in the messy world of a real organization, it's likely to be very difficult indeed. The development of new incentives regimes under these conditions faces three separate but interrelated problems - uncertainty around incentives, uncertainty around the task and the difficulties inherent in structuring credible new incentives (Table 1). While these challenges are present for any firm in a new arena, we suggest that established firms face particular hurdles not salient to startups.

-- Insert Table 1 about here -- 
Consider first those challenges that all firms face (Column A in Table 1). First, identifying exactly what an employee is likely to do without being paid to it (equation 1) or what his or her true interests are - is, in practice, a complicated task even for the individual employee. Putting to one side the important but thorny question of intrinsic motivation (Dyer \& Parker 1975), as the field work reported on in Kaplan (2005) suggests, actors may have multiple interests that run from the tangibly beneficial (preserving one's job, getting a promotion, commanding a larger number of resources) to the more intangibly beneficial (being seen as an expert or truth teller) and are subject to interpretation even by the employee. Moreover, individuals' interests may evolve over time as they gain experience, move into new positions, belong to different organizational groups and respond to changed incentive structures. As such, individuals may have multiple interests that can be differentially salient in different contexts, depending on both the incentives in that setting and the cognitive frames they hold. A particular cognitive frame about the nature of the technological change will make a particular set of interests salient in that situation. In any given context, individuals will seek to maximize some subset of these interests, which might include monetary compensation, but they may not have a full knowledge of the mapping from actions to private benefits (equation 1).

Second, there is tremendous task uncertainty in the mapping from actions to useful output (equation 2). As we suggested above, for any task of even moderate complexity inside a modern firm, managerial knowledge of these mappings is, at best, a partial and incomplete model that has evolved through many years of individual experience. In the case of an entirely new business opportunity, they are likely not to exist at all. In periods of relatively slow change, firms can develop quasi-stable sets of cognitive frames about what to do and how to do it. Major changes in the environment, on the other hand, place firms in a setting of particularly intense Knightian 
uncertainty in which these frames break down (Knight 1921/1965). As a result, managers must engage in a renewed process of sensemaking (Weick 1995), in which multiple interpretations about the future might emerge (Louis 1980; Winograd \& Flores 1986). Thus, while changes in cognitive frames can enhance adaptation in the face of discontinuities (Gavetti \& Levinthal 2000), it is not always clear to managers which change to make. When the new manager of the digital film business tells us that the things she's doing are most likely to lead to growth, how do we know if she's right?

Third, as situations become more dynamic and more ambiguous, it is even less clear what the employees' interests are and - this is critical for our argument - it is increasingly unlikely that an employer can easily gain this knowledge. Employees may also react in unanticipated ways to the "bonuses" that they are offered by an employer (equation 4). Designing the ideal incentive contract (equation 6) is thus a difficult task that typically takes place under conditions of severely limited information. To design a truly effective regime, an employer must determine not only which kinds of compensation are likely to be valuable to which kinds of employees (who values status? who control? who money?), but also the true form of equations (1-6). Then the employer must begin to build a relational contract with its employees that will persuade them that it will actually follow through and reward them according to the new "formula."

Designing incentives for ventures operating in new arenas is thus likely to be difficult for everyone that attempts it, but this line of argument gives us entrée into the question of why it is likely to be particularly difficult for established firms (Column B in Table 1). In trying to create a new incentive scheme, managers face two problems. The first is that they do not know what the scheme should look like. It took many years for employers to learn what equations (1-6) look like in the current business, and for the knowledge to become embedded both in the cognitive 
frames of the employees and employers, and in the routines and procedures of the firm. One of the things that an organization "learns" over time is precisely what actions are useful (the structure of equation 2), what employees would like to do even if we didn't pay them (the structure of equation 1), and what reasonable measures or indicators of "useful actions" look like (i.e., the most useful vector of measures, p). It is in this sense that an organizational routine is likely to have both a cognitive dimension - "This is how we go about hiring sales managers," "Here's what you should do when quality in the plant starts to slide" - and an incentive dimension - "Fred looks as though he's doing well in his new assignment," "The big guys say many things, but, take it from me, all you really need to do is pay attention to your day-to-day operating numbers and make nice to the boss." In fact we suspect that it may well be harder to learn how to evaluate and reward people than to learn how to do the work itself, since there is nearly always a distance between effort and outcome, and the relationship between them is often clouded by random shocks.

In an established business, it is likely to be the case that senior managers have developed intuitions over years of experience that enables them to evaluate their subordinates effectively ("Did you see what Chris has been doing in Asia? A hellish situation, but it's clear that she knows what she's doing"). Indeed the most senior managers are perhaps as likely to have been promoted on the basis of this knowledge as on the basis of task knowledge, since their primary task is to evaluate and reward the people that report to them. Taking an evolutionary perspective we suggest that interests, cognitive frames and incentives co-evolve, so that in any mature firm, they are intimately intertwined and deeply embedded in the way things are done. As such, the fact that managers might see things in a particular way is partially a product of their past and 
current incentives. Reciprocally, their perceptions of their own interests are shaped by their cognitive frames of the environment, the firm and the technology.

This will be particularly true for very successful managers who have been promoted on the basis of their subtle understanding of what should be done. If, over time, managers have developed the kinds of local, focused cognitive frames that are likely to get them promoted, then they may plausibly reject information alerting them to radical shifts in the environment as unimportant. Moreover as Ocasio (1997) argued in the development of his attention-based view of the firm, one of the contextual factors shaping the allocation of attention in the organization are what he calls the "rules of the game" - the incentive systems that structure the process by which interpretations are made. Since these incentives "regulate the attention of the organizational decision-makers so as to recognize and resolve those issues and activities most highly valued by the firm" (p. 199), a seemingly cognitive failure may well reflect a failure of the incentive regime.

As employers are faced with entirely new markets and technologies, or with the need to evaluate a manager who is running a highly risky, rapidly growing unit rather than a more mature, operationally focused one, their old intuitions as to what constitutes good effort are unlikely to be correct. Both employees and employers will need to relearn what constitutes good effort and identify appropriate measures of this effort under changed circumstances.

The second problem established firms encounter is that creating a relational contract around a new version of equation (6) is not straightforward. As we noted above, if employees and managers were fully rational and everyone had complete information, creating a new relational contract would be easy. One could, in principle, simply post an explanation of the new regime on the company web site, noting that while the firm might well be tempted ex post to fire 
people who take jobs with the new division when they perform according to the new incentive scheme, the company knows that if it acts this way it will not get anyone to take these new kinds of jobs in the future, and thus that it can be "trusted" to follow through.

But, in a world of uncertainty created by radical technological change, such a transition is likely to be far more difficult. Neither firm nor employee knows what "p" now looks like. And, it is difficult to build the mutual understanding that the firm will pay according to the new implicit contract even when it is in the firm's short term interest not to. Such instances are much more likely to arise during volatile periods (given that managers do not know what to reward, they are likely to choose the wrong "p"), and managers may not have a clear sense of the long-term benefits of holding to the new contract either. Worst of all, employees and employers may develop different senses of what the new incentive regime is - so that for any given action, employees may feel betrayed while managers believe that they are following through. Also, it may be simple for managers to recognize that they know little about the new technology but less obvious to them that their understanding of what makes for a good general manager is no longer appropriate. Alternatively, they may recognize the presence of the many complications outlined above and therefore believe that they cannot create an effective new incentive scheme. Any of these circumstances may lead employers to impose an existing incentive scheme on the entrepreneurial venture.

In summary, the need to use subjective measures and implicit contracts to motivate the organization to do one thing may make it very difficult to do another. If, as Nelson and Winter (1982) argue, routines are truces in the organization, and if these truces embody certain cognitive frames about the business and a set of incentives for acting on that understanding, then any changes in either the frames or the incentives will result in a breakdown of the truce. The lack of 
a truce raises the potential for conflict and misdirected effort. Thus, many managers will be loath to change organizational routines. If a new technology requires a new understanding (frame) in order to implement it successfully, it is less likely to be pursued by those in power positions who are invested in the existing system. Or, if it is pursued, managers may attempt to do so without disturbing that system, therefore assuring failure. Thus, inertial effects can be attributed to the degree of embeddedness of incentives with cognitive frames. This notion of incentives radically departs from principal-agent models and allows us to formalize Coriat and Dosi's (1998) insight that we need to consider " "what the agents believe to be their interests,' the ways they pursue them and the knowledge that they possess to be the evolutionary outcome of search, conflict and mutual adjustment sanctioned thereafter by rather inertial rules and organizational structures..." (p. 124).

\section{Discussion and conclusion}

What can we conclude from this discussion? First, as several authors have suggested, local routines - whether tacit knowledge, codes or procedures - are the product of not only a cognitive process, whereby individuals learn about how things are done, but also an incentive-related

process, whereby individuals learn what kinds of behaviors are likely to be rewarded. The effects of an incentive regime - "I act like this because this is in my best interests" - cannot be cleanly separated from cognition - "I act like this because this is what I believe to be the case." Rather, as we have suggested in this paper, cognition and incentives evolve simultaneously in a complex, reciprocal process. Second, with regard to the adoption of a radical new technology within an organization, we suggest that the barriers are both cognitive - "We know that this won't work and we doubt that it will ever make money even if it does" - and incentive-related - "You won't pay me for trying to learn." Moreover, because cognitive frames and incentives are tightly 
intertwined in an organization, any attempt to change one must be accompanied by a change in the other. The central problem, we suggest, is not that of cognition versus incentives, leadership versus structure, inertia versus conscious action and so on, but rather of how to develop a richer understanding of the ways in which these various elements interact - endogenously and dynamically - to shape the choices and behavior of the modern firm in the face of significant change.

An incentives-only story about firm response to radical technological change does not explain why it is so difficult to construct new regimes in response that change. Designing the ideal incentive contract is particularly difficult under the uncertain conditions and limited information of a discontinuity. Managers do not know what the scheme should look like, and, even if they do, they find it hard to put a new relational contract in place that employees will find credible. A cognition-only story is also inadequate. Much work in managerial cognition has tended to push the political pursuit of interests to the background and thus fails to address conflicting views or the politicized processes for producing collective meaning. Instead, managerial cognition research attributes firm inertia to individual cognitive inertia - an entirely psychological perspective. Our approach suggests that people can change their minds but this potential is shaped in a social context. The stickiness of frames is due not only to individual cognitive inertia but also to the ways that collective frames and incentives get embedded in systems and routines at the organizational level.

This discussion highlights three broad themes in which future research might yield high returns. The first is the relationship between the economic perspectives that we have briefly outlined above and the sociological or behavioral perspectives that dominate the current organizational literature. Our belief is that it is fruitless to debate whether a firm is really a 
complex social system or a collection of self-interested individuals. It would be surprising if it were not the case that all firms can be usefully viewed through both lenses, as a number of scholars have compellingly argued (see, for example, Ancona et al. 1999). A more fertile direction for research may be to explore the ways in which the economic dynamics of selfinterest and competition interact with the social and behavioral dynamics of the firm, much as Kogut and Zander (1996) examine how the interactions of incentives and identity shape coordination within the firm. Such a research program could explore questions about the degree to which the cognitive frames (and social structures more broadly) of a firm affect the motivation of its employees, whether certain kinds of formal structures and incentive systems are more likely to create certain kinds of social structures, and vice versa. Evidence of the potential benefits of this kind of research can be seen, for example, in Dosi, Levinthal and Marengo's (2003) models of how problem-solving is affected by incentive systems which show that, when a task is ill-specified, a shift in incentives to more local levels can improve the effectiveness of search behaviors.

The second set of implications for research is both theoretical and methodological. By suggesting that cognitive frames, interests and incentives interact and co-evolve, we are arguing that we cannot treat the firm as a macro-level whole. Rather, just as organizational economists insist that we need to understand the incentives of different parties inside the organization so, we believe, must we consider their cognitive frames. We must not reify the firm as a "cognizer," but rather must think of the firm as a collective of people, each with different interests and cognitive frames. Understanding firm response to radical technological change, or firm strategic action more broadly, requires that we show how a collective frame and ultimately a collective decision might emerge through the interactions of individuals (Spender 1998; Weick \& Roberts 1993), in 
particular under conditions of uncertainty. This view is consistent with recent calls to "bring work back in" to the study of organizations (Barley \& Kunda 2001) and to focus on the microprocesses within the organization (Johnson, Smith, \& Codling 2000). Such an approach should shed light on more proximal reasons for the heterogeneity of firm performance (in particular in the face of radical technological change) by linking micro processes to macro changes.

The third set of implications that this discussion opens up is practical and phenomenological. Much of the practitioner literature on the problem of firms' response to radical change has a very strong normative overtone. Firms that cannot change are "dinosaurs" or "elephants" and "teaching them to dance" is not only possible but essential (c.f., Gerstner 2002; Kanter 1989). Much of this work suggests that the failure of established firms reflects failings of the senior management team, and that better management, in the form of double loop learning (Argyris 1990), ambidextrous organizations (Tushman \& O'Reilly 1997), superior strategic processes (Eisenhardt 1989), or appropriately visionary and forward-thinking senior leaders (Burgelman 2002; Finkelstein 2003), can enable a firm to manage major transitions effectively. Implicit in this perspective is the view that large firms can be made significantly more flexible and responsive, and that movement in this direction generates unambiguously high private and social returns.

The model we develop in this paper opens up both hopeful and discouraging possibilities. The empirical literature suggests that established firms faced with radical technological change sometimes respond effectively. In some cases, this success occurs because the threat facing the organization is so profound that it disrupts the tight connection between cognitive frames, interests and incentives in the organization. But as a social movements perspective on framing (Benford 1997; Benford \& Snow 2000) has demonstrated, actors can also purposefully break and 
remake the connection between frames and incentives by mobilizing a powerful enough group around an alternative viewpoint. This perspective is consistent with an emerging stream of research on the evolution of technology and industry trajectories (Dowell, Swaminathan, \& Wade 2002; Garud \& Karnoe 2001; Garud \& Karnoe 2003; Lounsbury, Ventresca, \& Hirsch 2003; Rao, Monin, \& Durand 2003) ${ }^{4}$ that demonstrates that the purposeful action of firms and managers is an essential part of how industries respond to technological change. The findings from a field study on strategy-making in one firm during a period of radical technological change confirm this dynamic at an intra- rather than interfirm level (Kaplan 2005). The implication is that sophisticated managers who understand the tight linkages between cognitive frames, interests and incentives can intervene to create effective coalitions for radical action.

On the other hand, the organizational economics literature that we have outlined above suggests that this model may need to be tempered with the awareness that in some circumstances a firm's inability to change may be an adaptive response to its current environment, and that forcing the firm to change significantly - to do two things at once - may not only be risky and expensive but may also wreak havoc on the firm's ability to perform well in its current business. This notion of the problem of transition complements the work of Leonard-Barton (1992) who suggested that core competencies can become competency traps and of those sociologists who

\footnotetext{
${ }^{4}$ Garud and Karnoe $(2001 ; 2003)$ contrast the notions of path dependence and path creation. They argue that actors purposively manipulate circumstances, either to reproduce existing structures or to disengage from these structures and pursue different trajectories. While these authors bring agency back into the technology evolution story, they neglect power. For them, all options are open and the outcomes are just a matter of path creation. Those who bring social movements theory into analyses of technical change focus explicitly on how politics both constrain and enable agency.
} 
have suggested that firms attempting major changes run significant risks (Barnett \& Carroll 1995).

Research that attempted to assess the relative weight of these two alternatives in explaining the history of well-established firms faced with significant change would, we believe, be very productive. Potential research questions include: What types of cognitive frameincentives links contribute to inertial responses to technical change? What contributes to the embeddedness of frames? Under what conditions is purposeful action that disrupts ingrained cognitive frames more likely? What characteristics might a non-inertial firm possess?

Is it the case, for example, that the best performing firms in one generation are most likely to experience difficulty in the next? Such a finding would suggest that the second view based on the problem of transition is more correct. Or is it the case that well-managed firms are better both at managing their current businesses and in transitioning to new ones? Such a finding would suggest that the first view based on the potential for change provides more insight into the problem.

Our own suspicion is that both effects are important: that some firms are behind the production possibility frontier and for them a general upgrading of managerial capability by improving flexibility and responsiveness is unambiguously positive, others are so well-tuned to their existing operations that any attempt to change them significantly is likely to degrade performance. As the pace of change in the economy increases, learning more about which effect will dominate under which conditions is likely to become increasingly important. Given the potential for dislocation in the lives of hundreds or even thousands of people as the major institutions of our economy are faced with change, knowing when it makes sense to attempt to 
change them and when it's better to start from scratch should be a shared goal for organizational research.

This paper highlights the importance of the degree of embeddedness of cognitive frames and incentives in dealing with change. The less embedded they are, the more likely that alternative views of the world (views that could better accommodate radical technological change) can emerge. Yet, a deeply embedded system has its advantages - allowing smooth the decision-making processes and effective implementation of strategic actions. This is, of course, the "essential tension" of which Kuhn (1977) wrote: "Very often the successful scientist must simultaneously display the characteristics of the traditionalist and of the iconoclast" (p. 266). A model that views incentives and cognitive frames as intertwined in an organization recognizes that both are possible. Forces for tradition exist when cognitive frames and incentives are deeply embedded. Yet the iconoclastic effort to change is possible when managers can reshape the links between cognitive frames and incentives. 


\section{References}

Adams, J. S. (1963). Toward and understanding of inequity. Journal of Abnormal and Social Psychology, 67(5), 422-436.

Ancona, D. G., Kochan, T. A., Scully, M., Van Maanen, J., \& Westney, D. E. (1999). Managing for the future: organizational behavior \& processes (2nd ed.). Cincinnati, Ohio: South Western College Pub.

Anderson, E. M., \& Trinkle, B. (2005). Outsourcing the sales function: the real cost of field sales. Australia; Mason, Ohio: Thomson.

Argyris, C. (1990). Overcoming Organizational Defenses: Facilitating Organizational Learning. Boston: Allyn and Bacon.

Baker, G., Gibbons, R., \& Murphy, K. J. (1994). Subjective performance measures in optical incentive contracts. Quarterly Journal of Economics, 109(4), 1125-1156.

Baker, G., Gibbons, R., \& Murphy, K. J. (2001). Bringing the market inside the firm? 91(2), 212-218.

Barley, S. R., \& Kunda, G. (2001). Bring work back in. Organization Science, 12(1), 76-95.

Barnett, W. P., \& Carroll, G. R. (1995). Modeling Internal Organizational-Change. Annual Review of Sociology, 21, 217-236.

Barr, P. S., Stimpert, J. L., \& Huff, A. S. (1992). Cognitive Change, Strategic Action, and Organizational Renewal. Strategic Management Journal, 13(Special Issue), 15-36.

Benford, R. D. (1997). An insider's critique of the social movement framing perspective. Sociological Inquiry, 67(4), 409-430.

Benford, R. D., \& Snow, D. A. (2000). Framing processes and social movements: An overview and assessment. Annual Review of Sociology, pp. 611-639. 
Block, Z., \& MacMillan, I. C. (1993). Corporate venturing: creating new businesses within the firm. Boston, Mass.: Harvard Business School Press.

Block, Z., \& Ornati, O. (1987). Compensating corporate venture managers. Journal of Business Venturing, 2(1), 41-51.

Bower, J. L. (1997). Teradyne: The Aurora Project, 9-397-194. Harvard Business School Case Study.

Burgelman, R. A. (2002). Strategy is destiny: how strategy-making shapes a company's future. New York: Free Press.

Burns, T. (1961). Micropolitics: mechanisms of institutional change. Administrative Science Quarterly, 6, 257-281.

Chandy, R. K., \& Tellis, G. J. (2000). The incumbent's curse? Incumbency, size, and radical product innovation. Journal of Marketing, 64(3), 1-17.

Chesborough, H. W. (1999). The organizational impact of technological change: a comparative theory of national institutional factors. Industrial and Corporate Change, 8(3), 447-485.

Chesbrough, H. W. (2001). Assembling the Elephant: A Review of Empirical Studies on the Impact of Technical Change upon Incumbent Firms. In Burgelman, R. \& Chesborough, H. W. (Eds.), Comparative Studies of Technological Evolution (Vol. 7): JAI Press.

Christensen, C., M. (1997). The Innovator's Dilemma: When New Technologies Cause Great Firms to Fail. Boston: Harvard Business School Press.

Christensen, C. M., \& Rosenbloom, R. S. (1995). Explaining the attacker's advantage: Technological paradigms, organizational dynamics, and the value network. Research Policy, 24(2), 233-257. 
Christensen, C. M., Suarez, F. F., \& Utterback, J. M. (1998). Strategies for survival in fastchanging industries. Management Science, 44(12), 207-220.

Cohendet, P., \& Llerena, P. (2003). Routines and incentives: the role of communities in the firm. Industrial and Corporate Change, 12(2), 271-297.

Cooper, A. C., \& Schendel, D. (1976). Strategic Responses to Technological Threats. Business Horizons, 19(1), 61-69.

Coriat, B., \& Dosi, G. (1998). Learning how to govern and learning how to solve problems: on the co-evolution of competences, conflicts and organizational routines. In Chandler, A. D., Hagstrom, P. \& Solvell, O. (Eds.), The dynamic firm: the role of technology, strategy, organization and regions (pp. 103-133). Oxford; New York: Oxford University Press.

Daft, R. L., \& Weick, K. E. (1984). Toward a Model of Organizations as Interpretation Systems. Academy of Management Review, 9(2), 284-295.

Dosi, G., Levinthal, D. A., \& Marengo, L. (2003). Bridging contested terrain: linking incentivebased and learning perspectives on organizational evolution. Industrial and Corporate Change, 12(2), 413-436.

Dowell, G., Swaminathan, A., \& Wade, J. B. (2002). Pretty Pictures and Ugly Scenes: Political and Technological Maneuvers in High Definition Television. Advances in Strategic Management, 19, 97-133.

Dyer, L., \& Parker, D. (1975). Classifying outcomes in work motivation research: examination of intrinsic-extrinsic dichotomy. Journal of Applied Psychology, 60(4), 455-458.

Eisenhardt, K. M. (1989). Making Fast Strategic Decisions in High-Velocity Environments. Academy of Management Journal, 32(3), 543-576. 
Finkelstein, S. (2003). Why smart executives fail and what you can learn from their mistakes. New York: Portfolio.

Foss, N. J. (2003). Selective intervention and internal hybrids: Interpreting and learning from the rise and decline of the Oticon spaghetti organization. Organization Science, 14(3), 331349.

Garud, R., \& Karnoe, P. (2001). Path creation as a process of mindful deviation. In Garud, R. \& Karnoe, P. (Eds.), Path dependence and creation (pp. 1-28). Mahwah, N.J.: Lawrence Erlbaum.

Garud, R., \& Karnoe, P. (2003). Bricolage versus breakthrough: Distributed and embedded agency in technology entrepreneurship. Research Policy, 277-300.

Gatignon, H., Tushman, M. L., Smith, W., \& Anderson, P. (2002). A structural approach to assessing innovation: Construct development of innovation locus, type, and characteristics. Management Science, 48(9), 1103-1122.

Gavetti, G., Henderson, R., \& Giorgi, S. (2004). Kodak (A), 9-703-503. Harvard Business School Case Study.

Gavetti, G., \& Levinthal, D. (2000). Looking forward and looking backward: Cognitive and experiential search. Administrative Science Quarterly, 45(1), 113-137.

Gerstner, L. V. (2002). Who says elephants can't dance? inside IBM's historic turnaround. New York, NY: HarperBusiness.

Ghoshal, S. (1992). Andersen Consulting (Europe): Entering the Business of Business Integration, 392-055-1.Fontainebleau, France: INSEAD case study. 
Gioia, D. (1986). Symbols, scripts and sensemaking: creating meaning in the organizational experience. In Sims, H. P. J. \& Gioia, D. A. (Eds.), The Thinking Organization (pp. 4974). San Francisco: Jossey-Bass Publishers.

Hannan, M. T., \& Freeman, J. (1984). Structural Inertia and Organizational Change. American Sociological Review, 49, 149-164.

Henderson, R. M. (1993). Underinvestment and incompetence as responses to radical innovation: Evidence from the photolithographic alignment equipment industry. Rand Journal of Economics, 24(2), 248-270.

Henderson, R. M., \& Clark, K. B. (1990). Architectural Innovation: The Reconfiguration of Existing Product Technologies and the Failure of Established Firms. Administrative Science Quarterly, 35(1), 9-30.

Holmstrom, B. (1989). Agency Costs and Innovation. Journal of Economic Behavior \& Organization, 12(3), 305-327.

Holmstrom, B., \& Milgrom, P. (1991). Multitask Principal-Agent Analyses: Incentive Contracts, Asset Ownership and Job Design. Journal of Law \& Economics, 7, $24-52$.

Johnson, G., Smith, S., \& Codling, B. (2000). Microprocesses of institutional change in the context of privatization. Academy of Management Review, 25(3), 572.

Kanter, R. M. (1989). When giants learn to dance: mastering the challenge of strategy, management, and careers in the 1990s. New York: Simon and Schuster.

Kaplan, S. (2005). Framing contests: strategy making during a technological discontinuity: Wharton School Working Paper.

Kerr, S. (1975). On the folly of rewarding A, while hoping for B. Academy of Management Journal, 769. 
Kidder, T. (1981). The soul of a new machine. Boston: Little Brown.

Kiesler, S., \& Sproull, L. (1982). Managerial Response to Changing Environments: Perspectives on Problem Sensing from Social Cognition. Administrative Science Quarterly, 27(4), 548-570.

Knight, F. H. (1921/1965). Risk, uncertainty and profit. New York: Harper \& Row, Publishers (first published in 1921 Hart, Schaffner \& Marx).

Kogut, B., \& Zander, U. (1992). Knowledge of the Firm, Combinative Capabilities, and the Replication of Technology. Organization Science, 3(3), 383-397.

Kogut, B., \& Zander, U. (1996). What firms do? Coordination, identity, and learning. Organization Science, 7(5), 502-518.

Kuhn, T. S. (1977). The essential tension: selected studies in scientific tradition and change. Chicago: University of Chicago Press.

Landes, D., S. (1969). The Unbound Prometheus: Technological change and industrial development in Western Europe from 1750 to the present. Cambridge: Cambridge University Press.

Lazear, E. (2000). Performance pay and productivity. American Economic Review, 90(5), 13461361.

Leonard-Barton, D. (1992). Core Capabilities and Core Rigidities: A Paradox in Managing New Product Development. Strategic Management Journal, 13(Special Issue), 111.

Levin, J. (2003). Relational incentive contracts. American Economic Review, 93(3), 835-857. Levinthal, D. A. (1997). Adaptation on rugged landscapes. Management Science, 43(7), 934950. 
Lind, E. A., \& Tyler, T. R. (1988). The social psychology of procedural justice. New York: Plenum Press.

Louis, M. R. (1980). Surprise and Sense Making: What Newcomers Experience in Entering Unfamiliar Organizational Settings. Administrative Science Quarterly, 25(2), 226-251.

Lounsbury, M., Ventresca, M. J., \& Hirsch, P. M. (2003). Social movements, field frames and industry emergence: a cultural-political perspective on US recycling. Socio-Economic Review(1), 71-104.

Majumdar, B. A. (1982). Innovations, product developments, and technology transfers: an empirical study of dynamic competitive advantage, the case of electronic calculators. Washington, D.C.: University Press of America.

Nelson, R. R., \& Winter, S. G. (1982). An evolutionary theory of economic change. Cambridge, MA: The Belknap Press of Harvard University Press.

Ocasio, W. (1997). Towards an attention-based view of the firm. Strategic Management Journal, 18(Special Issue Supplement), 187-206.

Pfeffer, J. (1990). Incentives in Organizations: The Importance of Social Relations. In Williamson, O. E. (Ed.), Organization theory: from Chester Barnard to the present and beyond.New York: Oxford University Press.

Rao, H., Monin, P., \& Durand, R. (2003). Institutional change in Toque Ville: Nouvelle cuisine as an identity movement in French gastronomy. American Journal of Sociology, 108(4), 795-843.

Rothaermel, F. (2001). Incumbent's advantage through exploiting complementary assets via interfirm cooperation. Strategic Management Journal, 22(6-7), 687-699. 
Spender, J. C. (1998). The dynamics of individual and organizational knowledge. In Eden, C. \& Spender, J. (Eds.), Managerial and organizational cognition (pp. 13-29). London: Sage Publications.

Stark, D. (2000). For a sociology of worth, Keynote address for the Meetings of the European Association of Evolutionary Political Economy.November 2-4, 2000, Berlin.

Stinchcombe, A. L. (1965). Social structure and organizations. In March, J. G. (Ed.), Handbook of organizations (pp. 142-193). Chicago: Rand McNally.

Tripsas, M. (1997). Surviving radical technological change through dynamic capability: evidence from the typesetter industry. Industrial and Corporate Change, 6(2), 341-377.

Tripsas, M., \& Gavetti, G. (2000). Capabilities, cognition, and inertia: Evidence from digital imaging. Strategic Management Journal, 21(10/11), 1147-1161.

Tushman, M., \& O'Reilly, C. A. (1997). Winning through innovation: a practical guide to leading organizational change and renewal. Boston, Mass.: Harvard Business School Press.

Tushman, M. L., \& Anderson, P. (1986). Technological Discontinuities and Organizational Environments. Administrative Science Quarterly, 31(3), 439-465.

Utterback, J. M. (1994). Mastering the Dynamics of Innovation. Cambridge, Mass.: HBS Press.

Weick, K. E. (1995). Sensemaking in organizations. Thousand Oaks: Sage Publications.

Weick, K. E., \& Roberts, K. H. (1993). Collective mind in organizations: Heedful interrelating on flight decks. Administrative Science Quarterly, 38(3), 357-381.

Wheelwright, S. C., \& Clark, K. B. (1992). Revolutionizing product development: quantum leaps in speed, efficiency, and quality. New York, Toronto: Free Press. 
Winograd, T., \& Flores, F. (1986). Understanding computers and cognition: a new foundation for design. Norwood, N.J.: Ablex Pub. Corp. 
Table 1: Challenges to implementing new incentive regimes in new business arenas

\begin{tabular}{|c|c|c|}
\hline Challenges for... & ...any firm (A) & ...established firms in particular (B) \\
\hline $\begin{array}{l}\text { Understanding of } \\
\text { employee motivation, } \\
\text { costs of effort } \\
\text { (Equation 1) }\end{array}$ & $\begin{array}{l}\text { Because interests are context } \\
\text { dependent, in a dynamic } \\
\text { environment even employees may } \\
\text { not be clear on their own interests }\end{array}$ & $\begin{array}{l}\text { Both managers and employees may } \\
\text { hold well established beliefs about the } \\
\text { costs and benefits of actions derived } \\
\text { from historical experience }\end{array}$ \\
\hline \multirow{2}{*}{$\begin{array}{l}\text { Lack of task } \\
\text { knowledge (the } \\
\text { relationship between } \\
\text { action and outcome) } \\
\text { (Equation 2) }\end{array}$} & $\begin{array}{l}\text { New arena is characterized by } \\
\text { Knightian uncertainty }\end{array}$ & \multirow{2}{*}{$\begin{array}{l}\text { Firms are constrained by local search } \\
\text { and may see new market through old } \\
\text { lenses } \\
\text { Cognitive frames are embedded in } \\
\text { the existing incentive structure and } \\
\text { are hard to change }\end{array}$} \\
\hline & $\begin{array}{l}\text { Lack of knowledge about what is } \\
\text { the right thing to do: do not know } \\
\text { mapping from actions to useful } \\
\text { output }\end{array}$ & \\
\hline \multirow[t]{2}{*}{$\begin{array}{l}\text { Difficult to develop a } \\
\text { credible new } \\
\text { relational contract } \\
\text { (Equations } 4 \text { and } 6 \text { ) }\end{array}$} & $\begin{array}{l}\text { Measures of performance will be } \\
\text { particularly noisy in an uncertain } \\
\text { environment; neither the firm nor } \\
\text { the employee knows what } \\
\text { performance metrics }(p) \text { looks like }\end{array}$ & $\begin{array}{l}\text { Implementing a new incentive regime } \\
\text { violates the existing relational } \\
\text { contract with employees in the } \\
\text { traditional business. Therefore, the } \\
\text { organization will resist changes. }\end{array}$ \\
\hline & $\begin{array}{l}\text { Managers have no history of } \\
\text { rewarding employees according to } \\
\text { the new incentive scheme and } \\
\text { therefore it is not credible to } \\
\text { employees }\end{array}$ & $\begin{array}{l}\text { Routines are truces that embody } \\
\text { cognitive frames and incentives. } \\
\text { Changing either one breaks the truce } \\
\text { and could lead to conflict and } \\
\text { misguided efforts. Therefore, } \\
\text { managers will avoid making change } \\
\text { or do so while attempting to maintain } \\
\text { the truce. }\end{array}$ \\
\hline
\end{tabular}

